\title{
Manajemen Pengumpulan, Pendistribusian, dan Penggunaan Dana Zakat oleh Badan Amil Zakat Nasional sebagai Upaya Peningkatan Pemberdayaan Ekonomi Umat
}

\author{
Aftina Halwa Hayatika \\ UIN Raden Intan Lampung \\ aftinahalwa@gmail.com \\ Muhammad Iqbal fasa \\ UIN Raden Intan Lampung \\ miqbalfasa@radenintan.ac.id

\section{Suharto} \\ UIN Raden Intan Lampung \\ Prof.suharto@ radenintan.ac.id
}

\begin{abstract}
Abstrak Penelitian ini berjudul “ Manajemen Pengunpulan, Pendistribusian, dan Penggunaan Dana Zakat Oleh Badan Amil Zakat Nasional Sebagai Upaya peningkatan Kesejahteraan Ekonomi Umat. Berdasarkan dengan judul yang telah saya ambil dapat penelitian ini maka penelitian ini memiliki tujuan utama untuk mengetahui bagaimana implementasi serta dampak dari manajemen pengumpulan, pendistribusian, dan penggunaan dana zakat oleh badan amil zakat nasional terhadap upaya peningkatan pemberdayaan ekonomi umat. Manajemen adalah sarana untuk mengelola dana zakat agar terciptanya pengelolaan zakat dengan secara baik. Sebagaimana yang diketahui bahwasannya Badan Amil Zakat Nasional (BAZNAS) memiliki peran penting dalam pengumpulan, pendistribusian dan penggunaan dana zakat bagi masyarakat yang membutuhkan. Akan tetapi kini mulai berkembang pesatnya kata zakat sehingga timbulah lembaga- lembaga zakat yang juga memiliki fungsi tersendiri dalam pengelolaan zakat sehingga perlunya manajemen pengumpulan, pendistribusian, dan penggunaan dana zakat oleh Badan Amil Zakat Nasional (BAZNAS) dalam pengelolaannya. Manajemen pengumpulan, pendistribusian dan penggunaan dana zakat merupakan salah satu cara dalam peningkatan pemberdayaan ekonomi umat. Saat ini pemberdayaan ekonomi umat menjadi suatu kepentingan khusus bagi masyarakat yang membutuhkan untuk menganggkat derajat dan martabat mereka agar terlepasnya dari perangkap kemiskinan dan keterbelakangan ekonomi. Berdasarkan dengan konsep zakat sendiri bahwasannya tujuan dalam zakat tersebut memiliki fungsi yakni untuk meningkatkan kesejahteraan masyarakat dan pemberdayaan ekonomi umat.
\end{abstract}

\section{Kata Kunci Manajemen Dana Zakat, Baznas, Pemberdayaan Ekonomi Umat}

\section{PENDAHULUAN}

Zakat merupakan tugas kenegaraan.Pemerintah yang sah menurut pandangan Islam yakni pemerintah Islami wajib mengelola zakat, melalui badan tertentu yang berwenang mengurusinya.(Nofiaturrahmah, 2016) Oleh karenanya Pemerintah menetapkan dengan 
Undang-undang Republik Indonesia Nomor 38 Tahun 1999 tentang pengelolaan Zakat, bahwasanya dalam Undang-undang yang dimaksud dengan Pengelolaan zakat adalah kegiatan perencanaan, pengorganisasian, pelaksanaan, dan pengawasan terhadap pengumpulan dan pendistribusian serta pendayagunaan zakat. Setiap warga negara Indonesia yang beragama Islam dan mampu atau badan yang dimiliki oleh orang muslim berkewajiban menunaikan zakat, dan Pemerintah berkewajiban memberikan perlindungan, pembinaan dan pelayanan kepada muzaki, mustahiq, dan amil zakat pengelolaan zakat berasaskan iman dan takwa, keterbukaan, dan kepastian hukum sesuai dengan Pancasila dan Undang- Undang Dasar 1945 sesuai dengan misi dari BAZNAS.(Syafira, 2019)

Dalam prinsip ekonomi Islam terdapat beberapa instrument ekonomi untuk membantu kepentingan sosial seperti, pemanfaatan dana zakat, infaq, maupun sedekah untuk membiayai kesejahteraan umat. Bahkan dalam instrument ekonomi seperti zakat memiliki potensi besar apabila dapat dikelola secara baik oleh pemerintah.(Setiawan, 2019)Zakat sebagai rukun Islam merupakan kewajiban setiap muslim yang mampu untuk membayarnya dan diperuntukkan bagi mereka yang berhak menerimanya.(Afrina, 2020)Zakat pula merupakan suatu ibadah maliyah yang menyangkut hubungan antara manusia dengan sesama manusia dan hubungan antara manusia dengan Allah SWT. Di dalam hubungan antara sesama manusia zakat memiliki fungsi ta'awuniyah atau saling tolong menolong dimana seseorang yang memiliki kekayaan dapat menyisihkan sebagian hartanya untuk menolong orang lain yang sedang membutuhkan dengan ketentuan-ketentuan tertentu. Sedangkan di dalam hubungan antara manusia dengan Allah SWT, zakat merupakan suatu bentuk ibadah atau wujud ketaatan seorang hamba terhadap Tuhannya.(Nafiah, 2015)

Cara pandang Islam terhadap harta akan mendukung sistem ekonomi yang kokoh dan tumbuh secara berimbang dan berkesinambungan (balance and sustainable growth). (Khasanah \& Abidah Suryaningsih, 2019) Harta dipandang sebagai aliran (flow) bukan penumpukan (stock). Harta yang dimiliki, pada hakikatnya adalah milik Allah SWT. Allah-lah yang kemudian melimpahkan amanah kepada para pemilik harta, agar dari harta itu dikeluarkan zakatnya. Di sinilah sikap amanah dipupuk, sebab seorang muslim dituntut menyampaikan amanah kepada ahlinya. Sikap amanah, tidak hanya tumbuh dalam diri orang yang berzakat, tetapi juga pada para petugas atau amil zakat.Yakni dalam membagi dan menyalurkan seluruh harta zakat kepada yang berhak.(Ridwan, 2019) Agar terciptanya pengelolaan zakat yang profesional, terpercaya dan transparan menjadi sebuah instrumen penting yang dapat memakmurkan dan mengangkat derajat kaum muslim. Selain itu manfaat zakat lebih luas yaitu zakat berguna, bukan hanya bagi Indonesia saja tetapi untuk seluruh penduduk muslim dunia.(Triyani et al., 2017)

Jika lembaga zakat mampu menerapkan manajemen pendayagunaan zakat secara optimal serta memperhatikan tantangan baik yang berasal dari aspek internal mustahiq maupun dari aspek lembaga, maka lembaga zakat tersebut telah berhasil memenuhi amanahnya dalam hal peningkatan kualitas dan penguatan umat.(Ningrum, 2016)Selain itu banyak hikmah dan manfaat dari ibadah zakat, baik yang dirasakan oleh pemberi zakat (muzaki), penerima (mustahik), maupun masyarakat secara keseluruhan. Muzaki akan meningkat kualitas keimanannya, rasa syukur, kebersihan jiwa dan hartanya, sekaligus pengembangan harta yang dimilikinya. Mustahiq akan meningkat kesejahteraan hidupnya, terjaga agama, akhlaknya, meningkatnya etos kerja dan ibadahnya. Bagi masyarakat luas, hikmah zakat akan dirasakan 
dalam bentuk tumbuhnya rasa solidaritas sosial antar sesama anggota masyarakat, keamanan, ketenteraman, dan roda ekonomi berputar karena dengan zakat harta terdistribusi dengan baik, sekaligus akan menjaga dan menumbuhkembangkan etika dalam bekerja dan berusaha.(Zalikha, 2016)

Untuk mengetahui potensi zakat tersebut diperlukan suatu pengelolaan yang mampu mendayagunakan seluruh potensi zakat. Sedangkan untuk mendistribusikan dan mengelola dana zakat diperlukan penanganan konsep manajemen secara tepat dengan memperhatikan beberapa faktor yang dapat mempengaruhi pola pelaksanaan sistem zakat.(Novianti, 2018) Apabila dapat dikelola dengan baik dan amanah, zakat akan mampu meningkatkan kesejahteraan umat, mampu meningkatkan etos kerja umat serta sebagai institusi pemerataan ekonomi.(Hidajat, 2018)

Lembaga zakat telah didirikan oleh banyak negara muslim. Saat ini, beberapa negara muslim telah memperkenalkan sistem zakat resmi, tetapi tidak diimplementasikan secara optimal (tidak semua item zakat berada di bawah jejaring zakat). Jika lembaga ini dioperasionalkan secara profesional, pengentasan kemiskinan dapat diselesaikan.(Afrina, 2020)Oleh sebab itu disinlah letak penting dalam manajemen pengumpulan, pendistribusian dan penggunaan dana zakat untuk diimplementasikan dengan sebenar-benarnya. Tulisan ini akan mengkaji tentang bagaimana manajemen pengumpulan, pendistribusian, dan penggunaan dana zakat oleh badan amil zakat nasional untuk mencapai pemberdayaan ekonomi umat melalui penelitian dari beberapa jurnal atau artiker-artikel sebelumnya dimana dalam pembahasan tersebut terdapat polemik dalam manajemen zakat dalam pemberdayaan ekonomi umat, yang kemudian nantinya dapat menghasilkan inovasi baru untuk memperbaharui sistem manajemen zakat oleh badan amil zakat nasional untuk mencapai pemberdayaan ekonomi umat secara optimal.

Mengacu pada dasar pemikiran pada latar belakang diatas, maka penelitian ini perlu mengklarifikasi kembali sebuah permasalahan yang dihadapai sehingga sebuah kajian ini ditekankan untuk mengetahui : (1) Implementasi manajemen pengumpulan, pendistribusian dan penggunaan dana zakat oleh badan amil zakat nasional sebagai upaya peningkatan pemberdayaan ekonomi umat; (2) Dampak manajemen pengumpulan, pendistribusian dan penggunaan dana zakat oleh badan amil zakat nasional sebagai upaya peningkatan pemberdayaan ekonomi umat.

\section{LANDASAN TEORI}

\section{A. Manajemen Pengumpulan, Pendistribusan dan Penggunaan Dana Zakat A. Pengertian Manajemen}

Manajemen berasal dari kata prancis yaitu menegemen yang berarti seni untuk mengatur atau mengelola sesuatu sedangkan dalam bahasa inggris kata manage yang berarti menegendalikan atau mengelola. Oleh karena nya dapatlah disimpulkan bahwasannya manajemen adalah sebuah proses yang mengatur atau mengelola kegiatan serta prilaku seseorang agar menimbulkan suatu efek yang baik.

Manajemen adalah fungsi untuk mencapai sesuatu melalui kegiatan orang lain dan mengawasi usaha-usaha individu untuk mencapai tujuan yang sama. Manajemen adalah seni atau suatu ilmu pengetahuan. Mengenai ini pun sesungguhnya belum ada keseragaman pendapat, segolongan mengatakan bahwa manajemen adalah seni dan segolongan yang lain 
mengatakan bahwa manajemen adalah ilmu. Sesungguhnya kedua pendapat itu sama mengandung kebenarannya.(Novianti, 2018) Dengan demikian dapat disimpulkan bahwa manajemen merupakan suatu proses dalam mencapai suatu tujuan melalui kegiatan-kegiatan yang telah terorganisir dengan baik untuk mencapai hasil yang baik.

\section{B. Zakat}

\section{a) Pengertian Zakat}

Kata zakat dalam Bahasa Arab memiliki arti yang bervariasi. Istilah zakat berasal dari kata "zaka" yang berarti suci, jernih, bersih, berkah, berkembang, bertumbuh, bertambah, cerdik dan terpuji.Dalam ensiklopedia Islam Indonesia, zakat berarti tumbuh berkembang, bersih, atau baik dan terpuji.(Nurhayati, Sri. Siswanto, Dodik, Rahman, Taufikur. Sasongko, 2019)Arti kata bersih, suci dalam istilah zakat memberi makna membersihkan harta atau membersihkan diri dari sifat tamak, dengki, dendam, dan bakhil. Jadi dalam agama Islam pula terdapat suatu ajaran yang penting untuk diketahui bahwa sesungguhnya dalam harta orang kaya terdapat hak orang lain yang harus deikeluarkan dalam bentuk zakat, infaq, shadaqoh dan sebagainya agar tidak terjadinya kesenjangan antara orang kaya dan orang miskin.

Dalam Al-Qur'an, dasar definisi zakat tersebut dalam beberapa surat, diantaranya:

"Dan dirikanlah salat dan tunaikanlah zakat". Dan kebaikan apasaja yang kamu usahakan bagi dirimu, tentu kamu akan dapat pahalanya pada sisi Allah. Sesungguhnya Allah maha melihat apa-apa yang kamu kerjakan."(QS. Albaqarah:110)

Berdasarkan arti dari ayat surah dalam Al-qur'an tersebut, zakat merupakan haqqullah, artinya prinsip harta adalah milik Allah dan manusia sekedar seseorang yang diberi titipan.(Nurhayati, Sri. Siswanto, Dodik, Rahman, Taufikur. Sasongko, 2019)Oleh karena itu sesungguhnya zakat tidak hanya bersifat ghairu mahdhah (ketuhanan), tetapi juga maliyah ijtima'iyyah yang berarti sosial kemanusiaan.

Sedangkan dari sisi ekonomi, zakat menghambat terjadinya penimbunan harga kekayaan pribadi yang menjadi sumber terciptanya kesenjangan sosial ekonomi dalam masyarakat, dan sebaliknya zakat mendorong pertumbuhan dalam investasi dan menggugah etos kerja umat.(Haroen, 2009)

\section{b) Manfaat Zakat}

Pada hakikatnya zakat adalah sistem yang telah diisyaratkan Allah bagi umat Islam sebagai bentuk manifestasi hubungan antar manusia, terutama hubungan antara kaum berada (aghniya) dengan kaum yang kekurangan (duafa), sehingga tercapai keseimbangan dalam distribusi sosial.

Beberapa Manfaat zakat bagi orang yang berzakat (muzaki):

$>$ Untuk membersihkan jiwa orang berzakat darisifat sombong dan kikir, serta membersihkan hartanya dari bercampur baurnya dengan hak orang lain.

$>$ Dapat menghapuskan kesenjangan antara orang kaya dan orang miskin

$>$ Sebagai sarana pendekatan diri kepada Allah dan menyadari bahwa 
kebahagiaan dapat diraih dengan jalan menafkahkan hartanya dijalan Allah.

Menimbulkan rasa kasih sayang dan solidaritas sosial terhadap fakir miskin

Manfaat zakat bagi bagi penerima zakat (mustahiq):

$>$ Tercukupinya kebutuhan primer atau dharuriyat (makanan sehari-hari, tempat tinggal), maupun kebutuhan financial atau hifdzul maal (melindungi atau menyediakan kebutuhan)

$>$ Tercukupi materi serta batinnya akan menjadi lebih tenang.

\section{c) Dasar Hukum Zakat}

Dasar hukum zakat dapat dilihat dari ayat Al-qur'an yang telah tersebutkan sebanyak 82 kali yang setara dengan perintah salat, berbagai Hadist, serta terdapat pula ijma' dari para ulama

1.1 Terdapat ayat-ayat yang menerangkan tentang kewajiban zakat, salah satunya adalah firman Allah dalam (QS. Al-Baqarah:43) yang berbunyi:

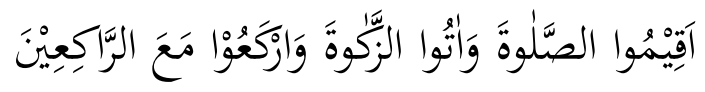

"Dan dirikanlah shalat dan tunaikanlah zakat dan rukuklah bersama orangorang yang rukuk”.

\subsection{Kewajiban berzakat dalam hadist}

Selain di dalam Al-qur'an, kewajiban zakat juga dapat kita temukan dalam berbagai hadist Rasulullah SAW, salah hadist yang sering kita jumpai adalah sabda Rasulullah SAW yang berbunyi:

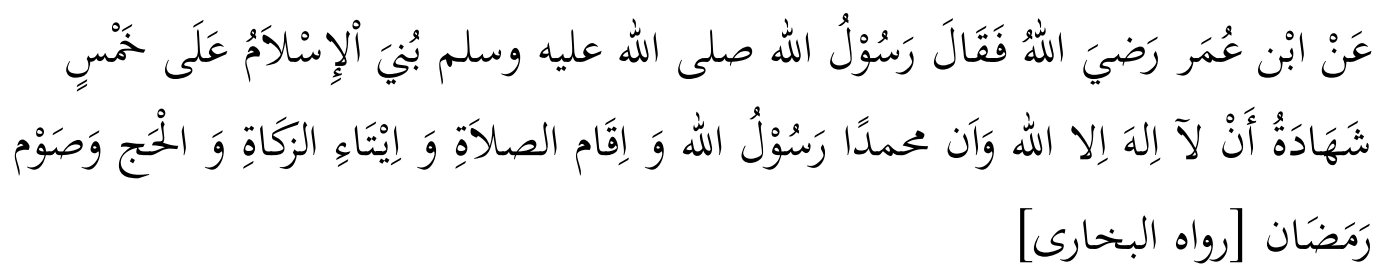

Artinya: "Dari Ibnu Umar r.a, dia berkata: Rasulullah saw. Bersabda "Islam berdiri atas lima hal yaitu: Bersaksi bahwa tidak ada Tuhan melainkan Allah dan Muhammad adalah Utusan Allah, mendirikan salat, memberikan zakat, hajidan puasa Ramadan (H.R. al-Bukhari)."

\subsection{Terdapat pula kewajiban zakat menurut ijma' para ulama}

Berdasarkan dari sudut pandang ijma' para sahabat, para sahabat bersepakat bahwa zakat adalah wajib.Seperti yang diterangkan dalam (QS. At-Taubah:34-35) yang artinya:

“... Dan orang-orang yang menyimpan emas dan perak dan tidak menafkahkan pada jalan Allah, maka beritahukanlah kepada mereka, (bahwa mereka akan mendapat) siksa yang pedih. Pada hri dipanaskan emas perak itu dalam neraka jahannam, lalu dibakar dengan dahi mereka, lambung, dan punggung mereka (lalu dikatakan) kepada mereka " inilah harta bendamu yang kamu simpan untuk dirimu sendir, maka rasakanlah sekarang (akibat dari) apa yang kamu simpan itu.” 
Dengan penjelasan di atas dapat dipahami bahwa dalil kewajiban zakat terdapat dalam Alquran, sunnah Rasulullah saw. dan ijmak para ulama maka sudah jelas bahwa kewajiban berzakat hukumnya farḍu 'ayn.(Khairuddin, 2020)

\section{Fungsi dari Manejemen Pengumpulan, Pendistribusian dan Pendayagunaan Dana Zakat}

Manajemen pengumpulan zakat merupakan suatu kegiatan yang dilakukan Badan Amil Zakat untuk mengkoordinasi, mengelola dan mengawasi usaha-usaha individu untuk dapat mencapai tujuan bersama.Sedangkan pemerintah tidak melakukan pengumpulan zakat melainkan hanya berfungsi sebagai koordinator, motivator, regulator dan fasilitator dalam pengelolaan zakat. Pengumpulan zakat dilakukan oleh Badan Amil Zakat yang dibentuk oleh pemerintah dan Lembaga Amil Zakat yang dibentuk oleh masyarakat dandikukuhkan oleh pemerintah.(Nofiaturrahmah, 2016)

Kemudian pengertian terkait distribusi adalah penyaluran (pembagian, pengiriman) kepada beberapa orang atau kebeberapa tempat. Lalu Pengertian lain mendefinisikan distribusi sebagai pembagian barang keperluan sehari-hari oleh pemerintah kepada pegawai negeri, penduduk, dan sebagainya.(Nasution et al., 2018)Berdasarkan pengertian diatas maka manajemen pendistribusian dana zakat adalah fungsi kegiatan dalam mengawasi usaha individu untuk mencapai tujuan melalui penyaluran (pembagian, pengiriman) barang keperluan sehari-hari berupa zakat kepada beberapa orang serta beberapa tempat.

Dalam pendayagunaan zakat ada tiga prinsip yang perlu diperhatikan yaitu 1.Diberikan kepada delapan asnaf 2.Manfaat zakat itu dapat diterima dan dirasakan manfaatnya.3.Sesuai dengan keperluan mustahik (konsumtif dan produktif). Zakat memiliki peranan yang sangat strategis dalam upaya pengentasan kemiskinan atau pembangunan ekonomi.(Nofiaturrahmah, 2016) Manajemen penggunaan dana zakat adalah fungsi dalam mencapai dan mengawasi penggunaan zakat sesuai dengan keperluan mustahik serta upaya strategis untuk pengentasan kemiskinan juga pembangunan ekonomi.

Berdasarkan pengertian dan fungsi dari manajemen pengumpulan, pendistribusian dan pendayagunaan dana zakat tersebut pemerintah serta badan amil zakat mempunyai peranan penting untuk mengelola dan mengawasi zakat agar tidak disalahgunakan juga bisa tersampaikan kepada masyarakat sesuai dengan kebutuhan sehingga dapat menuntaskan kemiskinan yang ada di masyarakat.

\section{Badan Amil Zakat Nasional}

Badan Amil Zakat Nasional (BAZNAS) merupakan badan resmi dan satu-satunya yang dibentuk oleh pemerintahan berdasarkan Keputusan Presiden RI No. 8 Tahun 2001 yang memiliki tugas dan fungsi menghimpun dan menyalurkan zakat, infaq, dan sedekah (ZIS) pada tingkat nasional. Lahirnya Undang-Undang Nomor 23 Tahun 2011 tentang Pengelolaan Zakat semakin mengukuhkan peran BAZNAS sebagai lembaga yang berwenag melakukan pengelolaan zakat secara nasional. Dalam UU tersebut, Baznas dinyatakan sebagai lembaga pemerintah nonstruktural yang bersifat mandiri dan bertanggung jawab kepada Presiden melalui Menteri Agama.(Faser, 2019)

BAZNAS Kabupaten yang dibentuk didasarkan pada Surat Keputusan Bupati. BAZNAS Kabupaten bertugas mengumpulkan, mendistribusikan dan mendayagunakan zakat sesuai dengan ketentuan agama. Badan Amil Zakat berfungsi sebagai jembatan antara muzaqi (pezakat) dan mustahiq (penerima).(Yughi, 2019) dengan itu dana zakat akan tersalurkan 
terhadap orang yang semestinya.

Kebijakan dari Baznas adalah menggunakannya sebagai penambah dana operasional kantor serta sistem penunjang manajemen Baznas. Sebagai bagian dari manajemen, Baznas juga melakukan evaluasi pengelolaan pendistribusian dan pendayagunaan zakat, menyusun pelaporan dan pertanggungjawaban pendistribusian dan pendayagunaan zakat, serta melakukan koordinasi pelaksanaan pendistribusian dan pendayagunaan zakat tingkat provinsi. (Mardiyah, 2018)

Adapun visi dari Baznas adalah unuk menjadi lembaga zakatnasional yang amanah, transparan dan professional serta dalam sebuah praktiknya, Baznas menunjukkan kinerja yang baik dan berhasil menyabet berbagai penghargaan seperti predikat Laporan Keuangan Terbaik untuk Lembaga Non Departemen versi Departemen Keuangan RI tahun 2008, penghargaan The Best in Transparency Management dan The Best in Innovative Programme dalam IMZ Award Tahun 2009, sertifikasi ISO 9001-2008 dan penghargaan The Best Quality Management dari Karim Business Consulting pada tahun 2011.(Iswanto, 2016)

Dengan itu Baznas memiliki tanggungjawab penuh terhadap pengelolaan, pendistribusian dan pengunaan dana zakat untuk tercapinya tujuan dari visi dan misi yang telah dibentuk serta dengan kepercayaan yang telah diberikan dari pemerintah membuat Baznas merasa perlu untuk terus meningkatkan kinerja yang lebih baik yaitu dengan cara menerapkan manajemen dalam pengelolaan, pendistribusian dan penggunaan dana zakat agar dalam pelaksanaannya dapat membuahkan hasil yang lebih baik dan efisien bagi peningkatan pemberdayaan ekonomi umat.

\section{E. Peningkatan Pemberdayaan Ekonomi Umat 1. Pengertian Peningkatan}

Menurut KBBI (Kamus Besar Bahasa Indonesia) arti kata peningkatan adalah proses, cara, perbuatan meningkatkan (usaha, kegiatan, dsb). Jadi peningkatan adalah lapisan dari sesuatu yang kemudian membentuk susunan, peningkatan berarti kemajuan, penambahan keterampilan dan kemampuan agar menjadi lebih baik.(Bahasa, 2007)

\section{Pemberdayaan Ekonomi Umat}

Istilah pemberdayaan semakin populer dalam konteks pembangunan dan pengentasan kemiskinan. Konsep pemberdayaan ini berkembang dari realitas individu atau masyarakat yang tidak berdaya atau pihak yang lemah(powerless). Ketidakberdayaan atau memiliki dalam aspek: pengetahuan, pengalaman, sikap, keterampilan, modalusaha, networking, semangat, kerjakeras, ketekunan, dan aspek lainnya.Kelemahan dalam berbagai aspek tadi mengakibatkan ketergantungan,ketidakberdayaan,dan kemiskinan.(Margayaningsih, 2018)

Pemberdayaan ekonomi umat, didasari dari pemahaman, bahwa suatu masyarakat dikatakan berdaya jika memiliki salah satu atau lebih dari beberapa variabel.

1. memiliki kemampuan untuk memenuhi kebutuhan dasar hidup dan perekonomian yang stabil.

2. memiliki kemampuan beradaptasi dengan perubahan lingkungan.

3. memiliki kemampuan menghadapi ancaman dan serangan dari luar.

4. Memiliki kemampuan berkreasi dan berinovasi dalam mengaktualisasikan diri dan menjaga ko-eksistensinya bersama bangsa dan negara lain.(Novianti, 2018) 
Pemberdayaan ekonomi umat pada dasarnya adalah suatu upaya mengoptimalkan dan meningkatkan kemampuan orang per orang, kelompok dan masyarakat dalam suatu lingkungan tertentu agar memiliki kemampuan untuk meningkatkan kualitas hidupnya secara mandiri, utamanya dalam masalah ekonominya.(Istan, 2017)

\section{Hasil dan Pembahasan}

Manajemen Pengumpulan, Pendistribusian, dan Penggunaan Dana Zakat Oleh Badan Amil Zakat Nasinal (BAZNAS) Sebagai Upaya pemberdayaan Ekonomi Umat

Zakat merupakan sebuah sistem pendistribusian kekayaan dari orang yang mampu terhadap orang yang kurang mampu dalam sebuah wilayah, sehingga memerlukan kehadiran Negara dalam pengelolaan zakat.Sehingga pemerintah membuatkan peraturan perundangundangan agar kewajiban zakat dapat terlaksana dengan sebaik-baiknya. Peraturan perundangundangan dibentuk oleh pemerintah bersandarkan pada dalil-dalil yang kuat yang bersumber dari Al-qur'an dan hadis-hadis Rasulullah saw, serta ijtihad para ulama.

Badan Amil Zakat Nasional merupakan lembaga yang mengatur dana zakat yang memiliki fungsi menghimpun atau mengumpulkan, mendistribusikan, dan pendayagunaan zakat, dari fungsi tersebut Baznas melakukan pengkoordinasian untuk pelaksanaan manajemen zakat agar berjalan sesuai prinsip pemerataan, keadilan, dan kewilayahan. Dengan manajemen pengelolaan zakat diupayakan untuk pengentasan kemiskinan akan lebih terukur berdasarkan data, serta lebih terpantau dari sisi kinerja lembaga pengelolanya.

Manajeman yang dilakukan BAZNAS dalam pengumpulan dilakukan dengan strategistrategi sebagai berikut:

- $\quad$ Strategi Pemasaran

Pemasaran merupakan kegiatan yang dirancang untuk mempromosikan dan mendistribusikan suatu produk.Pemasaran zakat dilakukan melalui program-program dimasjid, lembaga pendidkan, kesehatan, dakwah, dan sosial masyarakat.Program tersebut dibuat dalam tahapan-tahapan, kemudian dalam bentuk aktivitas, sehingga para mustahiq merasakan manfaatnya.Tujuannya adalah untuk memberikan informasi dan mengajak masyarakat agar masyarakat mau berzakat dan beramal.Bahkan menjadi sesuatu yang sangat bernilai, jika orang-orang yang awalnya tidak tau dan tidak memiliki niat untuk berzakat dan beramal menjadi berminat setelah menerima pesan-pesan tentang zakat yang disampaikan oleh organisasi pengelola zakat.

Salah satu media pemasaran yang dilakukan adalah melalui periklanan, seperti brosur, Koran majalah dan media cetak maupun elektronik lainnya. Media lain yang dapat digunakan antara lain website resmi BAZNAS atau media sosial lainnya seperti Instagram, Twitter, dan lain sebagainya.

Selain itu terdapat layanan konsultasi Zakat daring, yaitu konsultasi berupa pertanyaan terkait zakat, harta yang dikeluarkan zakat dan jumlah zakat yang harus dibayarkan.Selanjutnya lembaga zakat juga memiliki program jemput zakat.Layanan jemput zakat merupakan layanan yang dimiliki lembaga zakat untuk memudahkan dalam menyalurkan kewajiban sebagai seorang muslim.

Strategi pemasaran lain adalah dengan menyediakan konter Zakat dan Wakaf. Konter tersebut dapat disediakan di tempat-tempat umum seperti pada pusat perbelanjaaan, kantor pemerintah, tempat pelayanan umum, dan rumah sakit. Hal ini merpakan salah satu upaya 
yang dilakukan oleh Baznas dalam rangka memberikan kemudahan bagi masyarakat untuk membayarkan zakat infaq dan shadaqah dengan melalui konter ZIS.Kemudian tujuan utama keberadaan konter ZIS ini adalah supaya para muzaki mendapatkan pelayanan yang lebih dekat dan eksklusif, tidak hanya untuk keperluan pembayaran, tetapi juga berkonsultasi seputar ZIS serta memperoleh informasi lengkap melalui program BAZNAS.

- $\quad$ Strategi Penghimpunan Dana (Fundaising)

Penghimpunan dana merupakan upaya penghimpunan dana zakat dari muzaki melalui beberapa cara. Pendekatan yang harus dilakukan adalah melakukan identifikasi calon muzaki. Proses ini penting untuk pemetaan. Pendekatan selanjutnya adalah program jemput bola yang berarti dengan memberikan layanan jemput zakat bagi muzaki yang belum bisa mengantarkan zakatnya.

Beberapa contoh yang strategi penghimpunan dana zakat yang dilakukan adalah sebagai berikut:

1. Zakat melalui sistem penggajian

Zakat melalui sistem penggajian adalah sebuah bentuk pelayanan zakat dengan cara memotong langsung gaji seseorang pegawai/karyawan disebuah perusahaan.

Mekanisme pembayaran zakat melalui sistem penggajian adalah sebagai berikut:

a. Manajemen perusahaan memfasilitasi seluruh anggota (pimpinan dan karyawan) untuk menunaikan zakat dengan cara diperhitungkan dan dipotong langsung dalam daftar gaji

b. Karyawan mengisi formulir kesediaan membayar zakat melalui pemotongan gaji secara langsung yang ditujukan kepada bagian SDM atau bagian penggajan.

c. Pembayaran zakat dilakukan secara langsung dari gaji dan ditransfer ke rekening OPZ setiap bulannya

d. d. Bagian penggajian menyerahkan data karyawan yang membayar zakat kepada OPZ

e. Karyawan memperoleh dokumen berupa kartu Nomor Pokok Wajib Zakat (NPWZ), Bukti Setor Zakat (BSZ), dan Laporan Donasi atas Zakat yang ditunaikan.

2. Zakat Via E-card

Keberadaaan Anjungan Tunai Mandiri (ATM) hampir ada disetiap daerah bahkan tingkat desa sekalipun, yang memberikan peluang bai berbagai layanan pembayaran. Namun demikian, seiring dengan perkembanagannya, ATM yang disertai PIN kini mulai dinilai kurang praktis karena memasukan PIN sehingga memerlukan waktu untuk proses input PIN kedalam mesin tersebut. Kondisi ini awal mula munculnya konsep uang elektronik atau e-money atau e-wallet. E-money merupakan salah satu upaya untuk memuat alat pembayaran menggunakan kartu (APMK) yang dianggap lebih praktis tanpa menggunakan PIN sebagaimana yang telah diterapkan dalam pembayaran transportasi umum seperti MRT Train, busway, dan lain sebagainya.

OPZ juga dapat bekejasama dengan perbankan syariah atau BMT dalam menyediakan fasilitas pembayaran melalui menu pembayaran zakat di ATM dan BMT. BAZNAS juga dapat menginisiasi penerbitkan kartu NPWZ yang dapat difungsikn sebagai kartu Debit, ATM, atau e-wallet

3. Zakat Via Pembayaran Daring

Perkembangan teknologi website(web) 2.0 semakin meramaikan proses transaksi daring melalui portal, web dan blog di internet secara mudah, aman dan cepat. 
Memanfaatkan fasilitas ini, maka BAZNAS dapat menyediakan kemudahan menyediakan kemudahan layanan ZIS dan donasi lain malalui mekanisme pembayaran daring layanan pembayaran ZIS dan donasi lain melalui pembayaran darng atau e-payment dengan cara menjalin kerjasama dengan pihak perbankan syariah

4. Zakat Via Layanan Perbankan Syariah

Sebagai pilar ketiga dari ekonomi syariah, tentunya tidak etrlepas dari dua pilar lainnya, yaitu sektor rill dan sektor keuangan syariah, termasuk didalamnya perbankan syariah. BAZNAS telah memiliki rekening dan bekerjasama dengan seluruh perbankan syariah dalam proses penghimpunan zakat nasional

5. Zakat Via Konter

Keberadaan konter ZIS ini bertujuan untuk memudahkan masyarakat dalam melakukan pembayaran ZIS dan memperoleh informasi terkait program OPZ seperti yang dilakukan oleh BAZNAS.Selain menyediakan konter, BAZNAS juga memberikan layanan jemput zakat.

- Staregi Penyaluran dan penggunaan Dana Zakat

Penyaluran dan pendistribusian dana zakat merupakan pembagian hasil pengumpulan dana zakat kepada mereka yang berhak menerima (delapan ashnaf) secara merata dan adil. Tujuan dari pendistribusian dana zakat adalah meningkatkan kesejahteraan masyarakat secara adil dan merata, khususnya dalam aspek ekonomi sehingga dapat memperkecil kelompok masyarakat yang kurang mampu, yang pada akhrnya akan meningkatkan jumlah kelompok muzakki dan menurunkan jumlah mustahiq.

Sesuai dengan peraturan pemerntah Nomor 14 Tahun 2014 Pasal 25, zakat yang didistribusikan kepada mustahiq sesuai dengan syariat Islam.Prndistribusian zakat dilakukan berdasarkan skala prioritas dengan memperhatikan prinsip pemerataan, keadilan, dan kewilayahan. Zakat tersebut kemudian akan disalurkan kepada para mustahiq, sebagaimana yang telah di sebutkan dalam Al-Qur'an surah At-Taubah ayah 60, yang terdiri atas delapan kelompok penerima zakat (ashnaf), yaitu, fakir, miskin, amil, mualaf, riqob, gharim, fisabilillah, dan ibnu sabil.

Dengan pendistribusian ini badan amil zakat akan menyerahkan secara langsung dengan disaksikan oleh amil lain, tidak dengan mustahiq yang harus datang mengambil dan mengantri untuk mendapatkan bagian dari zakat.

Agar menjadi dana yang dapat dimanfaatkan untuk kesejahteraan dan pemberdayaan ekonomi umat terutama dalam pengentasan kemiskinan serta menghapuskan kesenjangan sosial, maka dana zakat harus dikelola secara professional dan bertanggung jawab. Peggunaan dana zakat ini dapat dikelola oleh masyarakat melalui kerjasama dengan pemerintah. Pendayagunaan dana zakat yang terkumpul didasarkan atas skala prioritas kebutuhan mustahiq dan kegunaan untuk usaha produktif.

\section{KESIMPULAN}

Manajemen merupakan sarana untuk mengatur dalam sebuah organisasi yang telah dibentuk agar terwujudnya keinginan yang hendak dicapai, dalam manajemen pengumpulan, pendistribusian, dan penggunaan dana zakat memiliki potensi yang besar untuk peningkatan pendayagunaan ekonomi umat yang didukung oleh peraturan-peraturan yang telah dibentuk dalam zakat serta sistem yang telah ada saat ini. Sistem pengelolaan dana zakat dapat membantu masyarakat pengelola, dan pemetintah dalam hal menjaga serta bertanggung jawab agar terjadinya keadilan, dan tidak ada kesenjangan yang terjadi. Serta dengan diterapkannya 
manajemen pengumpulan, pendistribusian, dan penggunaan dana zakat ini dapat menjadi daya tarik tersendiri dan inovasi terbarukan dari zakat terlebih dana zakat sebetulnya sangatlah dibutuhkan oleh mustahiq dalam peningkatan kesejahteraan dan pemberdayaan ekonomi mereka sehingganya sangat perlu diterapkannya manajemen dana zakat ini untuk kepentingan bersama.

\section{SARAN}

Bagi pengelola zakat, diharapkan untuk melakukan sosialisasi lebih luas dan melakukan tahapan pengelolaan yang lebih baik lagi, agar minat masyarakat untuk membayar zakat bertambah serta tetap memperhatikan pengumpulan, pendistribusian dan penggunaan agar tetap terjaga.Kemudian bagimasyarakat muzzaki, diharapkan dapat membantu menyebarkan informasi zakat kepada masyarakat lain agar dana zakat yang terkumpul akan bertambah banyak yang kemudian dengan itu peningkatan pendayagunaan zakat tercipta.Serta bagi pemerintah diharapkan dapat membuat kebijakan yang mampu meminimalkan dampak dari adanya manajemen pengumpulan, pendistribusian dan penggunaan dana zakat serta turut andil dalam pengembangan manajemen agar dapat membantu meningkatkan kesejahteraan dan pemberdayaan ekonomi umat.

\section{DAFTAR PUSTAKA}

Afrina, D. (2020). Manajemen Zakat Di Indonesia Sebagai Pemberdayaan Ekonomi Umat. EkBis: Jurnal Ekonomi Dan Bisnis, 2(2), 201-212.

Arief, A. (2020). Analisis Manajemen Distribusi Dana Zakat Dalam Program Meningkatkan Pendapatan Pedagang Kaki Lima (Studi Kasus Pada Baznas Kota Bengkulu). IAIN BENGKULU.

Bahasa, T. P. P. (2007). Kamus Besar Bahasa Indonesia Jakarta: Balai Pustaka. Ed.

Fahmi, M. S. S. (2018). Manajemen Pengumpulan, Pendistribusian Dana Zakat, Infaq, Shodaqah dan Wakaf (Ziswaf) di Lembaga Amil Zakat Nasional (Laznas) Yatim Mandiri. MALIA: Jurnal Ekonomi Islam, 9(2), 185-192.

Faser, M. (2019). Analisis Peranan Badan Amil Zakat Dalam Mengoptimalkan Zakat Produktif Terhadap Baznas Kota Palembang. Universitas Muhammadiyah Palembang.

Fitri, M. (2017). Pengelolaan Zakat Produktif sebagai Instrumen Peningkatan Kesejahteraan Umat. Economica: Jurnal Ekonomi Islam, 8(1), 149-173.

Haroen, N. (2009). Pedoman Zakat 9 seri. In N. Haroen (Ed.), Direktorat Pemberdayaan Zakat Direktorat Jendral Bimbingan Masyarakat Islam Depatermen Agama RI. Depatermen Agama Ri.

Haryanti, N., Adicahya, Y., \& Ningrum, R. Z. (2020). Peran Baznas Dalam Meningkatkan Perekonomian Masyarakat. IQTISADIYA: Jurnal Ilmu Ekonomi Islam, 1(1).

Hidajat, R. (2018). Penerapan Manajemen Zakat Produktif dalam Meningkatkan Ekonomi Umat di PKPU (Pos Keadilan Peduli Umat) Kota Makassar. Millah: Jurnal Studi Agama, 1(1), 63-84.

Istan, M. (2017). Pengentasan Kemiskinan Melalui Pemberdayaan Ekonomi Umat Menurut Persfektif Islam. Al-Falah: Journal of Islamic Economics, 2(1), 81-99.

Iswanto, B. (2016). Peran Bank Indonesia, Dewan Syariah Nasional, Badan Wakaf Indonesia dan Baznas dalam Pengembangan Produk Hukum Ekonomi Islam di Indonesia. Iqtishadia: Jurnal Kajian Ekonomi Dan Bisnis Islam STAIN Kudus, 9(2), 421-439.

Khairuddin, K. (2020). Persepsi Masyarakat Gampong Tanah Bara Kecamatan Gunung Meriah Kabupaten Aceh Singkil Terhadap Zakat Hasil Sawit. SYARIAH: Journal of 
Islamic Law, 2(2), 48-63.

Khasanah, I., \& Abidah Suryaningsih, S. R. I. (2019). Pendistribusian Dana Zakat Baznas Pasuruan Dalam Upaya Pemberdayaan Ekonomi Umat. Jurnal Ekonomi Islam, 2(3).

Mardiyah, S. (2018). Manajemen strategi BAZNAS dalam pengelolaan dana filantropi islam. I-Finance: A Research Journal on Islamic Finance, 4(1), 64-83.

Margayaningsih, D. I. (2018). Peran Masyarakat Dalam Kegiatan Pemberdayaan Masyarakat Di Desa. Jurnal PUBLICIANA, 11(1), 72-88.

Nafiah, L. (2015). Pengaruh Pendayagunaan Zakat Produktif Terhadap Kesejahteraan Mustahiq Pada Program Ternak Bergulir Baznas Kabupaten Gresik. EL-Qist: Journal of Islamic Economic and Business (JIEB), 5(1), 929-942.

Nasution, A. H., Nisa, K., Zakariah, M., \& Zakariah, M. A. (2018). Kajian Strategi Zakat, Infaq Dan Shadaqah Dalam Pemberdayaan Umat. Jurnal Ekonomi Bisnis Syariah, 1(1), 22-37.

Ningrum, R. T. P. (2016). Penerapan Manajemen Zakat dengan Sistem Revolving Fund Models Sebagai upaya Efektifitas Penyaluran Zakat Produktif (Studi pada Lembaga Manajemen Infaq Madiun). El-Wasathiya: Jurnal Studi Agama, 4(1), 1-21.

Nofiaturrahmah, F. (2016). Pengumpulan dan Pendayagunaan Zakat Infak dan Sedekah. ZISWAF: Jurnal Zakat Dan Wakaf, 2(2), 279-295.

Novianti, P. (2018). Manajemen Dana Zakat Pada Badan Amil Zakat Nasional (BAZNAS) Kota Bogor Dalam Upaya Pemberdayaan Ekonomi Umat. Jakarta: Fakultas Ekonomi dan Bisnis UIN Syarif Hidayatullah Jakarta.

Nurhayati, Sri. Siswanto, Dodik, Rahman, Taufikur. Sasongko, C. (2019). Akuntansi Dan Manajemen Zakat. In C. Nurhayati, Sri. Siswanto, Dodik, Rahman, Taufikur. Sasongko (Ed.), Jurnal Akuntansi Dan Manajemen. Salemba Empat.

Ridwan, M. (2019). Pengelolaan Zakat Dalam Pemberdayaan Masyarakat di Kota Cirebon. Syntax, 4.

Setiawan, D. (2019). Pengaruh Pendayagunaan Zakat Produktif Terhadap Kesejahteraan Mustahik Pada Program Ekonomi Mandiri (Eman) Di zakat Centre Kota Cirebon. Syntax Idea, 1(3), 59-80.

Syafira, R. D. (2019). Peranan Baznas Provinsi Sulawesi Tenggara Dalam Pemberdayaan Ekonomi Mustahiq Di Kota Kendari. Universitas Halu Oleo.

Triyani, N., Beik, I. S., \& Baga, L. M. (2017). Manajemen Risiko pada Badan Amil Zakat Nasional (BAZNAS). Al-Muzara'ah, 5(2), 107-124.

Triyawan, A. (2017). Analisis faktor-faktor yang mepengaruhi muzakki membayar zakat di BAZNAS Yogyakarta. Islamic Economics Journal, 2(1).

Yughi, S. A. (2019). Faktor Preferensi Individu Muzakki Lembaga Zakat Informal. IQTISHODUNA: Jurnal Ekonomi Islam, 8(1), 156-182.

Zalikha, S. (2016). Pendistribusian Zakat Produktif dalam Perspektif Islam. Jurnal Ilmiah Islam Futura, 15(2), 304-319. 